\title{
Evaluation and Strategy: Strengthening Indonesia Council of Representatives of the Regions
}

\author{
Dwi Putri Melati ${ }^{1, *}$, Nikmah Rosida $^{2}$ and Heni Siswanto ${ }^{2}$ \\ ${ }^{1}$ Doctoral Program in Law Science, Faculty of Law Lampung University, Lampung, Indonesia \\ ${ }^{2}$ Faculty of Law Lampung University, Lampung, Indonesia
}

\begin{abstract}
The Council of Representatives of the Regions emerged through the 1945 Constitution third amendment. The Council of Representatives of the Regions intended to represent regional interests and regional society in the central legislation making processes and products, to perform checks and balances principle on The People's Representative Council which is a political representation that brings and struggles the aspirations and interests of political parties at the central level. The Council of Representatives of the Regions also acts as a guardian of decentralization and regional autonomy. The most fundamental problem for The Council of Representatives of the Regions is its institutional weaknesses. In legislation weaknesses terms, budgeting, and supervision have affected The Council of Representatives of the Regions in maximizing its performances. The Law regarding Indonesia Legislative Branch does not mandate legislation as The Council of Representatives of the Regions tasks. This provision can not be used as a guideline to describe the scope of duties, which are the limits of their authority in The Council of Representatives of the Regions order. On the other hand, after the Constitutional Court Decision Number 92/PUU-X/2012 and Number 79/PUU-XII/2014 issued, the relations that were later present were the three-party discussion model of The People's Representative Council-The Council of Representatives of the Regions-President (Tripartite). Based on those facts, this article focuses on the evaluation of 15 years of The Council of Representatives of the Regions establishment and strategy to strengthen it.
\end{abstract}

Keywords: The Council of Representatives of the Regions, Authority, Legislation.

\section{INTRODUCTION}

The right to decentralization and regional autonomy are constitutional rights that can be deeply traced in the history of Indonesian state administration (Alisjahbana, A., \& Norio Usui Asian., 2003). The founding father who compiled the constitution was fully aware of the right of decentralization as an exceptional right for all regions in Indonesia. The right of decentralization as a constitutional right has become a national consensus as a fundamental right. It is evidenced by the inclusion of decentralization as a fundamental right (Timasheff, N. S., 1946). In every Indonesian constitution that existed in Indonesia.

The development of the decentralization rights in the post-independence period until the end of the millennium was disbelieved (Matsui. K., 2003). In this case, decentralization and regional autonomy are included in a system of power centralization as a form of rigid implementation of the Unitary State (Asshiddiqie, J., 2000). The fall of the new order after the Asian economic crisis was followed by constitutional reformation that delivered the unity of the Republic of Indonesia towards massive changes; one of those was the formation of the Indonesian

*Address correspondence to this author at the Jalan Purnawirawan Swadaya 5C, Gunung Terang Village, Langkapura District, Bandar Lampung City, Lampung Province, Indonesia; E-mail: rifandyritonga1@gmail.com,

dwputrii08@gmail.com parliament second chamber of The Council of Representatives of the Regions. The Council of Representatives of the Regions emerged in the Indonesian constitutional system through the Third Amendment of the 1945 Constitutions, which was established on November 21 $1^{\text {st }}, 2001$ (Majelis Permusyawaratan Rakyat Republik Indonesia., 2001).

After the third amendment of the 1945 Constitution, the parliamentary system of the Republic of Indonesia experienced significant changes. These changes contained in the provisions of Chapter VIIA, Article 22C and Article 22D of the 1945 Constitutions, which introducing The Council of Representatives of the Regions as a high-state institution that serves to represent regional interests in the constellation of national political policies along with political representation accommodated by The People's Representative Council (Gaffar, J.,M., 2003).

It is in line with the name. The existence of the second chamber is expected to be able to connect the interests of the central and regional governments, including the fight for the interests and aspirations of the people and regions in national policy and decision making along with other national political agendas (Rudy., 2017). Besides, the existence of The Council of Representatives of the Regions is expected to strengthen the parliamentary system and strengthen the democratic system in Indonesia (Gaffar, J.,M., 2003).

(c) 2021 Lifescience Global 
Indonesia, at the same time, requires a second chamber like The Council of Representatives of the Regions for two main reasons, namely:

1. The second chamber is used as an equilibrium between the central and regional governments along with the strengthener of democracy which requires both participation on political views and the participation of local people in national political decision making;

2. The second chamber needed to strengthen the unitarist, especially in terms of uniting the regions related to the issue of diversity (Rich, R., 2011).

Those two main reasons were the basis for the formation of The Council of Representatives of the Regions at the time of the amendment to the 1945 Constitution of the Republic of Indonesia (Warjiati, S., 2012), namely responding to the demands of reform to implement a decentralized-democratic government system to overhaul the authoritarian-oligarchiccentralistic government system (Nirahua, S. E. M., 2011).

This year celebrate the beginning of the fourth period of The Council of Representatives of the Regions within the Indonesia Constitutional System. Thus, the evaluation of its function is urgent. This article focuses on the evaluation of 15 years of The Council of Representatives of the Regions establishment and strategy to strengthen it.

\section{METHODOLOGY}

This research approach uses a normative legal approach, the data collected and analyzed comes from legislation and court decisions, which are related to the 15-year evaluation of the Regional Representative Council in Indonesia.

\section{DISCUSSION}

\section{The Struggle of Decentralization Representations}

The Council of Representatives of the Region's emergence during the reformation era is a positive response to the stagnation of the free channel for regions in Indonesia. The problem faced by Regional Representatives Council simply formulated in constitutional authority mentioned in 1945 Constitutions (Article 22D), thus debate arisen due to the dysfunctional exercise of The Regional
Representatives Council authority (Nirahua, S. E. M., 2011).

From a sociological perspective, The Council of Representatives of the Regions as a regional representative institution has several characteristics. First, its members are elected through General Elections as well as The People's Representative Council members. The process of direct election by the people confirms that The Council of Representatives of the Regions is an institution of political representation, not merely an envoy or representative. Second, as a representative political institution, its primary function is to operate the articulation function and aggregation of the local people's aspirations (National Democratic Institute, 2013). Third, the articulation and aggregation of these aspirations created in the legislative authority, supervision, and budgeting fields which are related to the region.

That is why the existence of The Council of Representatives of the Regions which is always related to the form of a union state, is not appropriate, because of the existence of the second chamber, The Council of Representatives of the Regions based on the need to equalize the power of the central government which has been hegemony by Political Parties. In this case, The Council of Representatives of the Regions intended to reduce or neutralize the political party's hegemony, despite its small role in the context of national political decision making through legislation (Rich, R., 2011).

As the second chamber and representing the region's interests, in terms of performing political activities, The Council of Representatives of the Regions conducts constructive opposition to the government (executive/president). It means that The Council of Representatives of the Regions will always monitor and evaluate national political policies that are not beneficial to the interests of the region. The Council of Representatives of the Regions as a representation of regional interests becomes a part of autonomous regions as a unit of the legal community to convey support and demand for various national political policies, especially those relating to regional interests.

However, the most fundamental problem for The Council of Representatives of the Regions is its institutional weaknesses. In terms of legislation weaknesses, budgeting and supervision have affected The Council of Representatives of the Regions in maximizing its performances. For example, in the 
legislative function, this can be seen from the first period of The Council of Representatives of the Regions legislation initiative (2004-2009). The Council of Representatives of the Regions submitted 12 proposals for an initiative legislation draft, 10 of which submitted to the People's Representatives Council, but there was only one was followed up.

Nearly to the end of the second period, The Council of Representatives of the Regions was constitutionally successful in fighting for more egalitarian constitutional authorities with The People's Representative Council and the Government. The Constitutional Court Decision on March 27, 2013, Case Register Number 92/PUU$X / 2012$ concerning the constitutionality of the duties and authority of The Council of Representatives of the Regions legislation which is equivalent to The People's Representative Council and the President made The Council of Representatives of the Regions become the core in fighting for regional interests at the national level, especially in terms of legislative authority.

It mentioned in the Constitutional Court Decision Case Number 92/PUU-X/2012, the Constitutional Court affirms that the implementation of State power is performed by the powered State. All-State Institutions are sub-systems of the whole system of administering State power. Therefore, the system of administering State power is concerned with the mechanism and applied procedures among these institutions in administrating State power. The system of administering State powerfully describes the way State institutions are given the power to achieve the objectives of the State. It means that there should not be a state institution when the legislative function is thoroughly dominated by the legislative power, which affected the inhibition of regional aspirations channelled through The Council of Representatives of the Regions.

The Constitutional Court Decision mentioned above philosophically emphasizes the importance of the position of The Council of Representatives of the Regions as the contents of the founding father, which have realized the weakness of a parties-based political representation system. In this case, the remaining idea is a balance between Political Representations (Political Parties) and territorial and functional representations that represent regional and group representatives (Winengan., 2020). The existence of alternative representation institutions outside The People's Representative Council: Firstly, citizens, especially in broader aspiration region, thus articulation and aggregation can be shared on various channels. Second, it intended to create equivalence between political representation determined by the number of voters (residents) and territorial representation. In terms of a diverse Indonesia (plural), this balance is needed to ensure the aspirations from the low population region to convey in the policy-making process at the national level. Third, strengthen checks and balances among representation institutions, so that the presence of The Council of Representatives of the Regions becomes the equalizer of The People's Representative Council. In this case, representative democracy probably got a higher quality. Due to the double-checked, the two chambers will guarantee the quality of all legislative products.

It can conclude that The Council of Representatives of the Regions and decentralization became a package of democracy in the current reform era. In this case, further observations are needed on how these roles can be maximized, especially in terms of regional law development and, more specifically, the formation of regional legal products.

\section{Evaluation of Legislation Power}

The theory of power separation should interpret that in performing its functions or authority, the branch of state power has exclusivity that cannot be touched or interfered by other branches of state power (Van Den Berge, L., 2017). It means that in the trias political theory, it is not possible to separate the branches of state power strictly. Therefore, the most probable is to strictly separate the function of each branch of state power based on the constitution, not to separate them from having no relationship at all completely (Ackerman, B., 2000).

So that in the ideal limitation of power, the principle of checks and balances through the constitution becomes a balance mechanism for mutual control between branches of state power. However, the mechanism of checks and balances can prevent the possibility of power abuse by branches of state power, in various developed countries, efforts to limit power as well as a mechanism of checks and balances commonly regulated in the constitution. Philosophically, the constitution was born to form and limit power while controlling power. A stable and democratic constitution is a constitution that detailly regulates the limits of authority and power of the legislative, executive, and judicial institutions equally so that it does not produce one of the supreme state institutions. 
In the context of a legal state that adheres to democracy, government supervision is performed by representative institutions, which has three main functions, namely:

1. legislation.

2. representation.

3. administrative oversight (administrative supervision) (Smelser, Neil J. and Baltes, Paul B., 2001).

Following its oversight function, parliament must have a healthy organ to perform its optimal role. Dati Fatimah said the idea of the importance of a credible and robust parliament faced several challenges and ideas (Syahid, Mar., 2019). The public argument published is the need for a supervisory institution completed by adequate capability and proven credibility, so that it can conduct supervision optimally.

Conceptually, Parliament has three main functions, namely the function of legislation, budgeting functions, and supervisory functions (de Rezende Martins, E. C., 2015). Although the three functions work in different ways and fields, they have a close relationship with one another. For example, public policies outlined in the form of laws must reflect in action programs that are realized in the form of budget support in The Indonesian Budget and Regional Government Budget. In conducting its supervisory function, the parliament accepts the public mandate to ensure that the implementation of policies conducted by the government will refer to the public interest (Beyme, $\mathrm{K}$. von., 2015).

Parliament must ensure how far the government can realize the common goals and interests approved upon by the public in the legislative and budgetary processes. Parliament can also get materials in perfecting legislation and budget products by findings in carrying out the supervisory function.

The practical implementation of the three legislative functions is supported by two other functions. Those are the function of articulation and aggregation of interests. Articulation of interests is the delivery of demands made by individuals and groups to the political system (Bailey, F. G., \& Bailey, F. G., 2018). In another sense, articulation is the channelling of people's aspirations (political infrastructure) to policymakers (political superstructure). The importance of interest is a process performed by the parliament in identifying, collecting, selecting, and formulating interests that have been articulated to become material for policy formulation. The process and the results of implementing legislative functions are the main goals for articulation and aggregation of interests. The output of the political system is expected to be the form of policies that respond to people's needs. Policy, whatever the form is, will produce feedback into new articulations and aggregations.

The feedback will be harder, even conflict, if the policy produced is not following the aspirations of the society (Navarro, J., et al., 2012). Therefore the three legislative functions are closely related to the articulation and aggregation of interests performed simultaneously with more balanced proportions. Inequality in performing the three functions of parliament will undoubtedly affect the whole performance of the parliament.

According to Article 22D paragraph (1), and paragraph (2) of the 1945 Constitutions, The Council of Representatives of the Regions, can propose and participate in discussing particular legislation draft with The People's Representative Council; and based on Article 22D paragraph (3) of the 1945 Constitutions, The Council of Representatives of the Regions can supervise specific laws and the implementation of the state revenue and expenditure budget. The mandate of the constitution explicitly guides the tasks of The Council of Representatives of the Regions in the domain of regional autonomy. The Council of Representatives of the Regions duty is comprehensive when referring to the provisions of Law Number 23 Year 2014 regarding Regional Government, The Council of Representatives of the Regions duty is a fundamental element that builds regional government entities whose management must focus on the security and political aspects which are simple matters of central authority. However, the provisions of the Law regarding the Indonesia Legislative Branch do not further elaborate on The Council of Representatives of the Regions duty. The Law regarding Indonesia Legislative Branch does not mandate legislation as the tasks of The Council of Representatives of the Regions. This provision can not be used as a guideline to describe the scope of duties, which are the limits of their authority in The Council of Representatives of the Regions order.

At the current stage, The Council of Representatives of the Regions has difficulty in translating the substance of regional autonomy into 
institution duty. This difficulty continues with the division of tasks in overlapping equipment. The absence of descriptive authority limitations affects The Council of Representatives of the Regions output (initiative legislation draft, views, and opinions, considerations), which can potentially be biased towards the mandate of Article 22D of the 1945 Constitution of the Republic of Indonesia.

The Constitutional Court's decision has reinstated how The Council of Representatives of the Regions legislative function is under the will of the 1945 Constitution. If previously the most influential relations in the legislative process were The People's Representative Council and the President, then after the Constitutional Court Decision Number 92/PUUX/2012 (Laksono, F. et al., 2015) and Number 79/PUU$X I I / 2014$, a new paradigm has emerged, in which the relations that were later present were the three-party discussion model of The People's Representative Council-The Council of Representatives of the Regions-President (Tripartite). However, if The People's Representative Council and the President continue to be involved until the decision-making stage or ratification of the bill, The Council of Representatives of the Regions involvement in discussing the law draft does not determine at the stage of approval or ratification of the bill.

Although The Council of Representatives of the Regions has the same legislative functions as The People's Representative Council, the function is not the same because The Council of Representatives of the Regions has legislative authority covering only the legislative authority in specific fields (specifically related to the region). The similarity in ownership of the legislative function, as well as its differences, has proven that the legislature in the Indonesian legislation system adopts a soft bicameralism system, not a strong bicameralism system. There are The People's Representative Council and The Council of Representatives of the Regions, who have the same position as legislative institutions but have unequal authority (Arinanto, S., 2014).

Although the authority of The People's Representative Council and The Council of Representatives of the Regions in the legislature is not persuasive compared to each other (soft bicameralism), the Constitutional Court Decision has confirmed that the position of The Council of Representatives of the Regions is not subordinate of The People's Representative Council. It reflects the importance of the second room in the legislature (Mochtar, Z., 2014). However, there is indeed a view that considers that the bicameral model is less efficient in the legislative process, where the legislative process will be slow, and the required budget will increase (Isra, S., 2014) to can be applied to provide a maximum time limit to complete a bill.

On the other hand, the two-room model has the advantage that the legislative process is more productive because all tasks and authorities can be conducted by the two rooms so that both constitutional functions can optimize. The presence of two rooms will be beneficial because it can guarantee all legislative products and surveillance measures can be checked by a double-check process. The advantages of this double-check system are increasingly felt when the upper house that checks and revises a draft law has a different membership with a different composition from the lower house (Towards Effective Bicameral in Order to Strengthen DPD's Legislative Function, 2007).

Based on this explanation, there is no doubt that the tripartite model in the legislative process and the application of a soft bicameral system can indeed implement. In other words, it is inevitable that in the legislative process, from the preparation stage of the National Legislation Program to the deliberation of the Law, The Council of Representatives of the Regions is involved in it. Fear of inefficiencies in the legislative process can be eliminated because, with two rooms, the legislative process will be more productive (Nurbaningsih, E., 2015). Following the Constitutional interpretation of the Constitutional Court, the legislative process is the will of the 1945 Constitution.

The Constitutional Court has affirmed in its decision that The Council of Representatives of the Regions legislative authority must be positioned accordingly under the 1945 Constitution. However, it could still be possible to make a "misinterpretation" in performing the Constitutional Court's decision, such as problems that occur with the substance of the Law regarding the Indonesia Legislative Branch. In this context, Maruarar Siahaan gave his views regarding the nature of the Constitutional Court's decision, which was final and binding. According to Maruarar, state officials must be bound to respect the constitutional rules and override lower legislation. It was born from the principle that every law/law and statutory rules of all authorities authorized by the constitution, may not contradict the 1945 Constitution as the highest fundamental or legal law (Siahaan, M., 2014). 
As a judicial policy that becomes a new legal policy, the Constitutional Court's decision is not to implement by itself (self-implementing), and its implementation is a political process (Charles A. Johnson et al., 2014). Although in reality there are decisions that can perform by themselves (self-implementing) in the sense that such decisions can apply as new legal norms, do not require changes in the law in the long process as appropriate the establishment of legislation that must first revise the substance of the rules following the policies contained in the Constitutional Court's decision. Nevertheless, more often, the decisions that form the legal policy are non-self-implementing because they cover new policies and have an inlaw and involve broader parties (Pile Tukan, J. P., \& Tyesta ALW, L., 2018).

The preceding cannot achieve without excellent and effective political communication. That is because conceptually, the representative institution has three main functions; legislative functions, budget functions, and supervisory functions. All three are supported by two other functions: the articulation and aggregation functions of the interests of the local fund community and the function of political communication. Although the five functions work in different ways and scopes, the five functions have a close relationship with each other.

\section{Strengthening The Regional Representative Spirit}

The Council of Representatives of the Regions is the implementation of territorial representative functions, which empirically is even more difficult than the political representative. Representative territories are heavier because regional representatives (senators) must be able to formulate a paradigm from various diverse regional interests, both in aspects of culture and decentralized structures (regional characteristics in terms of organizational aspects, namely special regions. While the political representative is relatively easier since these days, The People's Representative Council members represent political interests that are still centralistic. In other words, political decentralization has not manifested in political parties.

The problem is the large number of parliamentarians whose political commitments identified very weak in conducting their duties and functions as people's representatives (Dupont, J. C., et al., 2019) Thus, weak parliamentary capacity has been the prior problem that has occurred in Indonesian governance. Parliament's capacity is weaker than the capacity of the executive and bureaucracy, although executive capacity has not reached the public expectations. It is affected by several reasons, as follows; firstly, the process of bureaucratic recruitment generally takes place with a technocratic process (prioritizing technical qualifications), while the process of parliamentary recruitment takes place with a political process that is the opposite of technocratic principles. Second, the background of parliamentarians is very diverse, especially when seen from the knowledge and experience aspects. Most new members of parliament do not understand the matters of governance (legislative functions, etc.). The limited capacity of the parliament is also caused by poor political education in the community as well as in political parties. Third, it is the inequality of the supporting system among the executive-bureaucratic parliament (legislative). Executives own and control staff, large organizations, budgets, information, data, programs, and others to maintain daily governance. On the other hand, the legislature is lack of supporting resources.

It should not happen to The Council of Representatives of the Regions. Thus the goal of being a representative territorial will not happen. The realization of the national legislation program in the form of legislation will be strongly related to its duties and authority as regional representation in The Council of Representatives of the Regions. We must approve that there are many conflicts between various sectoral laws and legislation regulations concerning decentralization and regional autonomy. Moreover, the lack of party faction consistency in The People's Representative Council towards regional interests must be noted by The Council of Representatives of the Regions to be the front guard in forming regional legislation. Thus, The Council of Representatives of the Regions must control and struggle for all these complex processes for the region priority.

For those purposes, several legislation drafts that have not yet been completed at the internal level should be immediately discussed and realized. Secondly, the implementation of society compliment needs for legal products that have a direct effect on people's prosperity must be realized immediately. It is intended to facilitate the process of creation of superior communities that can realize the implementation of development in all fields. Fulfillment of legal certainty is one of the objectives of the formation of the regulations which directly engage in society. It is expected that the realization of these legal needs could emerge the 
implementation of programs that encourage society's prosperity.

The Council of Representatives of the Regions, as a regional representative institution, realizes that regional needs are not only related to clothing, food, and shelter but also related to adequate infrastructure that must be developed by all of us. Therefore, this is a challenge for all of us to be a part of realizing legislation that focuses on people's prosperity. Achieving social justice places more emphasis on being responsive to the needs of citizens (Tomz, M. R., \& Houweling, R. P. V., 2012).

\section{CONCLUSION}

The political dynamics after the amendment to the 1945 Constitution gave its color to state and politics in Indonesia. These constitutional and political changes affect the institutionalization of politics along with the level of community participation development. Although it increasingly shows its dominance over the executive role, the role of parliament (The People's Representative Council) has not positively correlated with the realization of prosperity and intelligence among citizen lives. The increasing role of parliament shows more achievement quantity compared to other substances of regional autonomy in creating people's prosperity, which should be their primary task and function as citizen representatives. In this case, the existence of The Council of Representatives of the Regions completed by individual figures who were supposed to be non-partisan would undoubtedly provide its characteristic in providing balance in parliamentary life in Indonesia. The Council of Representatives of the Regions as the second chamber should be able to play a significant balancing force, especially in the field of legislation. The presence of The Council of Representatives of the Regions intended to represent regional interests and regional society in the processes and products of central legislation, as a counterweight to the principle of checks and balances on The People's Representative Council which is a political representation that brings and struggles the aspirations and interests of political parties at the central level. It is in line with regional interests. The Council of Representatives of the Regions also acts as a guardian of decentralization and regional autonomy. In the context of regional legal product development, The Council of Representatives of the Regions must be able to play a role in laying the foundations of the central law that provide a way for The Council of Representatives of the Regions to supervise the development of regional law. In this case,
The Council of Representatives of the Regions is required to be able to articulate and aggregate regional interests into the process of forming legislation and supervision on the development of regional law. At the level of policy implementation, the presence of The Council of Representatives of the Regions can connect the aspirations of regional law development and national development policies.

\section{REFERENCES}

Alisjahbana, A., \& Norio Usui Asian. 2003. Local development planning and budgeting in decentralized Indonesia: update. International Symposium on Indonesia's Decentralization Policy, Problems and Policy Directions, (September 2003). Retrieved from https://www.researchgate.net/profile/ Norio Usui/publication/295605831_Local_Development_Pla nning_and_Budgeting_in_Decentralized_Indonesia_Update/li nks/56 cbf59b08ae96cdd06fda2e.pdf?origin=publication_deta il

Arinanto, S. 2014. Examination of Decisions of the Constitutional Court Related to the Regional Representative Council of the Republic of Indonesia, Law Center of the Regional Representative Council of the Republic of Indonesia. Jakarta, 2014. 23.

Asshiddiqie, J. 2000. Otonomi Daerah dan Parlemen di Daerah. Lokakarya tentang Peraturan Daerah dan Anggaran Bagi Anggota DPRD se Provinsi (baru) Banten, Banten, 2 Oktober.

Ackerman, B. 2000. "The new separation of powers." Harvard Law Review, 114(3), 634 https://doi.org/10.2307/1342286

Beyme, K. von. 2015. "Parliamentary Government." In International Encyclopedia of the Social \& Behavioral Sciences: Second Edition (pp. 511-514). Elsevier Inc. https://doi.org/10.1016/B978-0-08-097086-8.93085-X

Bailey, F. G., \& Bailey, F. G. 2018. A Political System. In Stratagems and Spoils (pp. 1-18). Routledge. https://doi.org/10.4324/9780429497094-1

Dupont, J. C., Bytzek, E., Steffens, M. C., \& Schneider, F. M. 2019. Which kind of political campaign messages do people perceive as election pledges? Electoral Studies, 57, 121130. https://doi.org/10.1016/j.electstud.2018.11.005

De Rezende Martins, E. C. 2015. "Parliaments, History of". In International Encyclopedia of the Social \& Behavioral Sciences: Second Edition (pp. 515-519). Elsevier Inc. https://doi.org/10.1016/B978-0-08-097086-8.62093-7

Laksono, F., Triningsih, A., Ramdan, A., \& Karmadaniah, I. 2015 "Implementation of Constitutional Court Decision Number 92/PUU-X/2012 In Relation To The Authority of Regional Representatives Council in The Making of Laws." Jurnal Konstitusi, Volume 12, Nomor 3. https://doi.org/10.31078/jk1236

Gaffar, J.,M. 2003. Dewan Perwakilan Daerah Dalam Sistem Ketatanegaraan Republik Indonesia. Jakarta: Sekretariat Jenderal MPR RI dan UNDP.32.

Isra, S. 2014. An Expert Statement In The Constitutional Court Decision Number 79 / PUU-XII / 2014. 71.

Matsui. K., 2003. "Decentralization in Nation-State Building of Indonesia, Institute of Developing Economies, Japan External Trade Organization." IDE Research Paper No. 2

Majelis Permusyawaratan Rakyat Republik Indonesia, 2001. Buku Keempat Jilid 1 A: Risalah Rapat Komisi A Ke-1 s/d Ke-3 Tanggal 4 November s/d 6 November 2001, Masa Sidang Tahunan MPR RI. 
Malik, A., Supriyono, B., Hermawan \& Mindarti, L.,I. 2020. "Balance Of Political And Managerial Approaches To Government In Direct And Simultaneous Local Elections In Indonesia." International Journal of Advanced Science and Technology, Vol. 29, No. 05,2020), 104-112.

Mochtar, Z. 2014. A. Expert Statement In The Constitutional Court Decision Number 79/PUU-XII/2014. 80.

Nirahua, S. E. M. 2011. "Kedudukan dan Kewenangan Dewan Perwakilan Daerah dalam Sistem Ketatanegaraan Indonesia." Jurnal Hukum IUS QUIA IUSTUM, 18(4), 585603.

https://doi.org/10.20885/iustum.vol18.iss4.art6

National Democratic Institute. 2013. Political Parties and Democracy in Theoretical and Practical Perspectives, Washington, dc, national democratic institute (NDI), 1-140

Navarro, J., Vaillant, N. \& Wolff, F. 2012. Measuring the efficiency of deputies in the deputies in the French parliament: The contribution of non-parametric border techniques, French journal of political science, vol. 62, (4), 611-636. https://doi.org/10.3917/rfsp.624.0611

Nurbaningsih, E. 2015. "Implikasi Putusan Mahkamah Konstitusi Nomor 92/PUU-X//2012 dan Alternative Model Hubungan Kelembagaan Terkait Pembentukan Undang-Undang." Mimbar Hukum Vol. 27, Nomor 1. https://doi.org/10.22146/jmh.15906

Pile Tukan, J. P., \& Tyesta ALW, L. 2018. "DPD (Regional Representative Council), As A State Agency of Indonesian State System, Runs The Authority of Its Role And Function To Create the Existence of Bicameral System In Indonesia." Diponegoro Law Review, 3(1), 64. https://doi.org/10.14710/dilrev.3.1.2018.65-75

Rich, R. 2011. Designing the DPD: Indonesia's Regional Representative Council. Bulletin of Indonesian Economic Studies, 47(2), 263-273. https://doi.org/10.1080/00074918.2011.585953

Rudy. 2017. Pembangunan Hukum Di Daerah Membangun Legislasi Yang Mengayomi. Bandar Lampung: AURA (CV. Anugrah Utama Raharja). 18. https://doi.org/10.5840/thought194621154
Rich, R. 2011. Designing the DPD: Indonesia's Regional Representative Council. Bulletin of Indonesian Economic Studies, 47(2), 263-273. https://doi.org/10.1080/00074918.2011.585953

Siahaan, M. 2014. A Statement From The Expert In The Constitutional Court Decision Number 79/PUU-XII/2014. 96.

Smelser, Neil J. and Baltes, Paul B. 2001. International Encyclopedia of the Social \& Behavioral Sciences, Pergamon. https://doi.org/10.1016/B0-08-043076-7/01186-4

Syahid, Mar. 2019. "Fungsi Pengawasan DPRD Riau: (Dilema Kepentingan Partai Politik dan Kepentingan Publik)." Momentum , vol. (7)2, 97-115. https://doi.org/10.29062/mmt.v8i2.31

Timasheff, N. S. 1946. General Theory of Law and State. Thought, 21(1), 187-189. https://doi.org/10.5840/thought194621154

Towards Effective Bicameral in Order to Strengthen DPD's Legislative Function, .2007. accessed in http://www.saldiisra.web.id/index.php/buku-jurnal/jurnal/19 national journal / 273-towards-bicameral-effective-in-orderstrengthening-function-legislation-dpd.html

Tomz, M. R., \& Houweling, R. P. V. 2012. Political Pledges as Credible Commitments. Working Paper.

Van Den Berge, L. 2017. Montesquieu and judicial review of proportionality in administrative law: Rethinking the separation of powers in the neoliberal era. European Journal of Legal Studies, 10(1), 203-233.

Warjiati, S. 2012. Sistem Ketatanegaraan Indonesia Pasca Amandemen UUD 1945. Al-Daulah: Jurnal Hukum Dan Perundangan Islam, 2(2), 185-207. https://doi.org/10.15642/ad.2012.2.2.185-207

Winengan. 2020. "The Local Political Policies: The Dynamics of the Political Party Coalition in the Election Contestation of the Governor West Nusa Tenggara Province Indonesia." International Journal of Criminology and Sociology, 2020, 9, 350-356. https://doi.org/10.6000/1929-4409.2020.09.33

\section{https://doi.org/10.6000/1929-4409.2021.10.173}

(C) 2021 Melati et al.; Licensee Lifescience Global.

This is an open access article licensed under the terms of the Creative Commons Attribution License (http://creativecommons.org/licenses/by/4.0/) which permits unrestricted use, distribution and reproduction in any medium, provided the work is properly cited. 